\title{
ПИТАННЯ ЕКОНОМІЧНОЇ ДОСТУПНОСТІ ЛІКАРСЬКИХ ЗАСОБІВ НА АФРИКАНСЬКОМУ КОНТИНЕНТІ
}

\author{
() О. М. Євтушенко, Осама Абузаїд Мохамед Нур Ахмед
}

\author{
Національний фрармацевтичний університет, Харків
}

\begin{abstract}
Резюме: стаття присвячена дослідженню економічної доступності лікарських засобів на Асрриканському континенті за допомогою методології Всесвітньої організації охорони здоров'я (World Health Organization - WHO) та Міжнародної програми дій в охороні здоров'я (Health Action International - HAI), а також показників економічної доступності в різних країнах. Отримані результати свідчать про недостатню економічну доступність основних лікарських засобів в афрриканських країнах. Проведений порівняльний аналіз у країнах Африки свідчить про складну ситуацію з лікарським забезпеченням у Судані, де показники доступності гірші від показників інших африканських країн у 7 - 10 разів, і в 20 - 30 разів - порівняно 3 європейською країною.
\end{abstract}

Ключові слова: лікарські засоби, економічна доступність, африканські країни, Судан, Німеччина.

Вступ. Фармацевтичний ринок Африканського континенту в структурі світового фрармацевтичного ринку належить до сегменту ринків, що «фрормуються», 3 передбачуваним приростом в 13 - $14 \%$ на рік. На даний момент низькі доходи населення, недостатній рівень державного фрінансування, особливості клімату і місцерозташування не дозволяють досягти необхідних обсягів медичної та фрармацевтичної допомоги. На даний момент Африка зі своїм найвищим тягарем хвороб у світі зберігає серйозну залежність від імпорту ліків. Імпортна продукція становить від 80 до 100 \% в деяких африканських країнах, незважаючи на те, що доходи населення і система медичного забезпечення абсолютно не розрахована на споживання високовартісних лікарських засобів (далі Л3). Вкрай гостро проблема фрізичної та економічної доступності ЛЗ стоїть в країнах Східного Середземномор'я.

Метою роботи $є$ проведення аналізу економічної доступності ЛЗ в країнах Східного Середземномор'я, а також порівняння отриманих показників з показниками європейських країн. В дослідженні брали участь такі країни, як Судан, Єгипет, Ліван, Уганда та Ефіопія. Для порівняння отриманих показників доступності та визначення їх рівня, проведено порівняння показників між собою, а також 3 показниками розвиненої країни Європейського континенту. Як еталон прийнято Німеччину як країну з однією з розвинутих фрармацевтичних ринків світу і найсильнішою системою охорони здоров'я, яка виділяє найбільше коштів на медичне і фрармацевтичне забезпечення серед усіх країн ЄС.

Методи дослідження. У даній роботі враховували фрармакоекономічні методи аналізу, а також методологію Всесвітньої організації охорони здоров'я (World
Health Organization - WHO) та Міжнародної програми дій в охороні здоров'я (Health Action International - HAl) «Вимірювання цін на лікарські засоби, їх наявності, доступності та компонентів цін», дані, отримані при обстеженнях цієї методології [1, 4, 6-11]; відомості з регіональних і національних джерел [12]; а також наукові публікації з даної теми [2, 3, 5]. Дані щодо цін на лікарські препарати та вартості курсу лікування отримано шляхом вивчення роздрібних цін в аптеках вищеназваних країн.

У загальній сукупності в дослідженні брали участь Л3, які застосовують для лікування хронічних захворювань та які включено до міжнародного переліку, рекомендованого для постійного моніторингу (дослідження) Всесвітньою організацією охорони здоров'я.

Результати й обговорення. Відповідно до рекомендацій ВООЗ обрано основні ЛЗ для лікування 14 найбільш поширених захворювань, які дозволять провести міжнародні дослідження (тобто мається на увазі наявність однакових препаратів за міжнародного назвою у всіх вищенаведених країнах). Також $€$ допустимим включення в даний перелік ЛЗ, що найбільш важливі для лікування особливих захворювань в певних країнах. Так, для країн Африки такими препаратами є засоби для лікування малярії. Рекомендований ВОО3 перелік наведено в таблиці 1. У дослідженні брали участь генеричні Л3, продавані за найнижчою ціною. Далі визначали економічну доступність досліджуваних лз із урахуванням співвідношення вартості лікування даним препаратом (відповідно до міжнародних протоколів лікування) та денної заробітної платні найнизькооплачуваного некваліфікованого державного службовця в даних країнах.

Для проведеня дослідження необхідні дані з одноденної заробітної платні державного службовця. Так,

ISSN 2312-0967. Pharmaceutical review. 2015. № 4 
Фармацевтичний менеджмент, маркетинг та логістика Pharmaceutical management, marketing and logistics

Таблиця 1. Міжнародний перелік лЗ, рекомендований ВООЗ / HAІ для включення в національні системи моніторингу цін, доступності ЛЗ та порівняльного міжнародного аналізу

\begin{tabular}{|c|c|c|c|c|}
\hline № & Хвороби, стан & Назва лЗ & Дозування & Лікарська фрорма \\
\hline 1 & Астма & Сальбутамол & 100 мкг/доза & інгалятор \\
\hline 2 & Діабет & Глібенкламід & $5 \mathrm{Mr}$ & капсули / таблетки \\
\hline 3 & \multirow{3}{*}{$\begin{array}{l}\text { Серцево-судинні } \\
\text { захворювання }\end{array}$} & Атенолол & $50 \mathrm{Mr}$ & капсули / таблетки \\
\hline 4 & & Каптоприл & $25 \mathrm{Mr}$ & капсули / таблетки \\
\hline 5 & & Симвастатин & $20 \mathrm{мг}$ & капсули / таблетки \\
\hline 6 & Депресія & Амітриптилін & $25 \mathrm{Mr}$ & капсули / таблетки \\
\hline 7 & \multirow[t]{4}{*}{ Інфекційні захворювання } & Ципрофлоксацин & $500 \mathrm{Mr}$ & капсули / таблетки \\
\hline 8 & & Ко-тримоксазол & 8+40 мг/мл & суспензія \\
\hline 9 & & Амоксицилін & $500 \mathrm{мг}$ & капсули / таблетки \\
\hline 10 & & Цесртріаксон & 1 г/амп. & ін'єкція \\
\hline 11 & Захворювання ЦНС & Діазепам & $5 \mathrm{Mr}$ & капсули / таблетки \\
\hline 12 & \multirow[t]{2}{*}{ Біль, запалення } & Диклооренак & $50 \mathrm{мг}$ & капсули / таблетки \\
\hline 13 & & Парацетамол & 24 мг/мл & суспензія \\
\hline 14 & Виразкова хвороба & Омепразол & $20 \mathrm{Mr}$ & капсули / таблетки \\
\hline
\end{tabular}

одноденна заробітна платня державного службовця склала:

- Судані - 1,846 доларів США (12 суданських фрунтів);

- Єгипті - 5,80 доларів США (40 єгипетських фрунтів);

- Лівані - 14,93 доларів США (22500 ліванських фрунтів);

- Уганді - 2,031 доларів США (5200 угандійських шилінгів);

- Eqрiопії - 0,7479 доларів США (14 ефріопських бір),

- у Німеччині - $110 €$ (євро) 125 \$.

При визначенні економічної доступності препаратів використовувався модиорікований коефріцієнт адекватності платоспроможності, який включає найнижчу роздрібну ціну препарату (або вартість курсу лікування) і середню заробітну платню за певний період часу (1):

$$
C_{\text {a.s. }}=\frac{\bar{P}}{W_{\text {a.w. }}} \times 100 \%
$$

де $C_{a . s .}$ - коефріцієнт адекватності платоспроможності;

$\bar{P}$ - найнижча роздрібна ціна курсу лікування препаратом-генериком;

$W_{\text {a.w. }}$ - середня заробітна платня за відповідний період часу (в нашому випадку була обрана одноденна заробітна платня державного службовця в кожній з досліджуваних країн).

у данному дослідженні - чим менше коефіцієнт адекватності платоспроможності, тим менше коштує пацієнту курс лікування обраним препаратом.
Результати наведено в таблиці 2. Аналіз показує, що доступність ЛЗ в деяких африканських країнах знаходиться на незадовільному рівні. Наприклад, в Судані навіть в державному секторі на генеричні препарати призначаються досить високі ціни. Так, за інформацією літературних джерел, ціни на оригінальні препарати могли перевищувати міжнародні базові ціни в 18 разів, ціни на генеричні препарати - в 5.

що стосується загального сприйняття показників доступності, найменші показники має Судан, найбільшу доступність - Єгипет. При порівнянні доступності ЛЗ в країнах Африки та Німеччини, то для лікування диклофренаком в Німеччині потрібно витратити 0,24 одноденної заробітної платні, а в Судані - 5,3, що в 22 рази більше; аналогічно, для лікування парацетамолом суданські пацієнти витрачають в 10 разів більше.

Таким чином, аналіз економічної доступності основних ЛЗ свідчить, що Єгипет і Ліван забезпечує досить низьку вартість основних Л3, яка наближається за рівнем до країн Європейського регіону. Особливо в Єгипті більшість показників економічної доступності препаратів відповідає показникам країни з розвиненим фрармацевтичним ринком і потужною системою охорони здоров'я - Німеччини. Так, показники Єгипту практично ідентичні з показниками Німеччини за цінами Diclofenac, Atenolol, Captopril, Glibenclamide, Ceftriaxone, Diazepam, і навіть нижче - з препаратами Salbutamol, Amitriptyline, протималярійних засобів.

При цьому в Судані відзначаються досить високі ціни і, відповідно, низька доступність на ряд таких препаратів, як Diclofenac, Paracetamol, Captopril, Simvastatin, Amitriptyline. Так, пацієнту в Судані необхідно затратити в 22 рази більше коштів на лікування диклофренаком, ніж пацієнтові в Німеччині. А лікуван-

ISSN 2312-0967. Фармацевтичний часопис. 2015. № 4 
Фармацевтичний менеджмент, маркетинг та логістика Pharmaceutical management, marketing and logistics

Таблиця 2. Економічна доступність основних генеричних лЗ (за найнижчою ціною), що входять в міжнародний перелік, рекомендований для проведення постійного моніторингу в країнах Східного Середземномор'я і країнах порівняння

\begin{tabular}{|c|c|c|c|c|c|c|c|c|c|}
\hline \multirow{3}{*}{ № } & \multirow{3}{*}{$\begin{array}{l}\text { Міжнародна } \\
\text { назва Л3 }\end{array}$} & \multirow{3}{*}{$\begin{array}{l}\text { Дозування, } \\
\text { лік. форма }\end{array}$} & \multirow{3}{*}{$\begin{array}{c}\text { Основне } \\
\text { терапев- } \\
\text { тичне } \\
\text { застосу- } \\
\text { вання ЛЗ } \\
\text { (хвороба, } \\
\text { стан) }\end{array}$} & \multicolumn{6}{|c|}{$\begin{array}{c}\text { Економічна доступність ЛЗ (ГНЦ), кількість денних зарплат } \\
\text { для оплати курсу лікування } \\
\end{array}$} \\
\hline & & & & \multicolumn{3}{|c|}{$\begin{array}{c}\text { країни Східного } \\
\text { Середземномор'я }\end{array}$} & \multicolumn{2}{|c|}{$\begin{array}{c}\text { країни } \\
\text { порівняння } \\
\text { Афрриканського } \\
\text { регіону }\end{array}$} & \multirow{2}{*}{$\begin{array}{c}\text { країна } \\
\text { порівнян- } \\
\text { ня Європ. } \\
\text { регіону } \\
\text { Німеччина }\end{array}$} \\
\hline & & & & $\begin{array}{l}\text { Су- } \\
\text { дан }\end{array}$ & Єгипет & Ліван & $\begin{array}{l}\text { Edpi- } \\
\text { опія }\end{array}$ & Уганда & \\
\hline 1 & Diclofenac & $\begin{array}{c}50 \text { mg cap/ } \\
\text { tab }\end{array}$ & Артрит & 5,34 & 0,30 & 0,63 & 0,60 & 0,59 & 0,24 \\
\hline 2 & Salbutamol & $\begin{array}{c}100 \mathrm{mcg} / \\
\text { dose inhaler }\end{array}$ & Астма & 1,60 & 0,30 & 0,29 & 1,76 & 1,45 & 0,94 \\
\hline 3 & Paracetamol & $\begin{array}{l}120 \mathrm{mg} / 5 \mathrm{ml} \\
\text { susp. }\end{array}$ & $\begin{array}{c}\text { Біль, } \\
\text { запалення }\end{array}$ & 0,24 & 0,31 & 0,40 & 0,43 & 0,26 & 0,02 \\
\hline 4 & Atenolol & $\begin{array}{l}50 \mathrm{mg} \mathrm{cap} / \\
\mathrm{tab}\end{array}$ & Гіпертензія & 0,67 & 0,12 & 0,17 & 1,20 & 0,30 & 0,12 \\
\hline 5 & Captopril & $\begin{array}{c}25 \mathrm{mg} \mathrm{cap} / \\
\text { tab }\end{array}$ & Гіпертензія & 3,25 & 0,48 & 0,67 & 3,43 & 2,74 & 0,45 \\
\hline 6 & Simvastatin & $\begin{array}{l}20 \text { mg cap/ } \\
\text { tab }\end{array}$ & $\begin{array}{c}\text { Гіпер- } \\
\text { холесте- } \\
\text { ринемія }\end{array}$ & 2,10 & 2,14 & 0,33 & 2,48 & 1,86 & 0,98 \\
\hline 7 & Amitriptyline & $\begin{array}{c}25 \mathrm{mg} \mathrm{cap} / \\
\text { tab }\end{array}$ & Депресія & 2,24 & 0,26 & 0,38 & 2,56 & 1,73 & 0,91 \\
\hline 8 & Glibenclamide & $\begin{array}{c}5 \mathrm{mg} \text { cap/ } \\
\text { tab }\end{array}$ & Діабет & 0,50 & 0,15 & 0,16 & 0,43 & 1,15 & 0,10 \\
\hline 9 & $\begin{array}{l}\text { Artemether+ } \\
\text { Lumefantrine }\end{array}$ & $\begin{array}{c}20+120 \mathrm{mg} \\
\text { cap/tab }\end{array}$ & Малярія & 0,14 & 0,32 & 0,50 & 0,12 & 1,06 & 0,77 \\
\hline 10 & Ciprofloxacin & $\begin{array}{c}500 \text { mg cap/ } \\
\text { tab }\end{array}$ & $\begin{array}{l}\text { Респ. інфф. у } \\
\text { доросл. }\end{array}$ & 1,17 & 0,60 & 0,70 & 0,86 & 0,54 & 0,16 \\
\hline 11 & Amoxicillin & $\begin{array}{c}500 \mathrm{mg} \text { cap/ } \\
\text { tab }\end{array}$ & $\begin{array}{l}\text { Респ. інф. у } \\
\text { доросл. }\end{array}$ & 0,88 & 0,40 & 0,61 & 1,26 & 0,40 & 0,68 \\
\hline 12 & Ceftriaxone & $\begin{array}{c}1 \mathrm{~g} / \mathrm{vial} \\
\text { injection }\end{array}$ & $\begin{array}{l}\text { Респ. інфф. у } \\
\text { доросл. }\end{array}$ & 3,76 & 0,64 & 0,67 & 1,78 & 0,48 & 0,57 \\
\hline 13 & $\begin{array}{l}\text { Co- } \\
\text { trimoxazole }\end{array}$ & $\begin{array}{c}40+200 \\
\mathrm{mg} / 5 \mathrm{ml} \\
\text { susp. }\end{array}$ & $\begin{array}{l}\text { Респ. інф. у } \\
\text { дітей }\end{array}$ & 0,39 & 0,20 & 0,32 & 0,28 & 0,40 & 0,76 \\
\hline 14 & Diazepam & $\begin{array}{c}5 \mathrm{mg} \mathrm{cap} / \\
\text { tab }\end{array}$ & $\begin{array}{c}\text { Тревожний } \\
\text { стан }\end{array}$ & 0,10 & 0,05 & 0,11 & 0,14 & 0,13 & 0,08 \\
\hline 15 & Omeprazole & $\begin{array}{c}20 \mathrm{mg} \mathrm{cap} / \\
\text { tab }\end{array}$ & Виразка & 2,68 & 0,72 & 0,88 & 1,97 & 1,15 & 0,63 \\
\hline
\end{tabular}

ня парацетамолом обійдеться йому ж у 10 разів дорожче, лікування каптоприлом обійдеться дорожче в 7 разів. Порівняння показників доступності в Судані 3 країнами Афрриканського регіону також супроводжується ситуацією, коли показники доступності на ЛЗ в 3-10 разів гірші, ніж у сусідніх країнах зі схожою системою охорони здоров'я.

Проблеми Африканського регіону зумовлені масою чинників, проте складно утримати ціну на лікарські засоби при таких макроекономічних явищах, як девальвація валюти, криза в економіці, зниження ВВП, що насамперед позначається на доступності життєво важливої продукції. Економічна доступність
лЗ лежить не тільки в площині зниження ціни, багато залежить від реалізації державних програм реімбурсації, які необхідні в країнах, що розвиваються, коли вартість ЛЗ відшкодовується хоча б частково, тоді не настільки важливо, скільки коштує препарат.

що стосується наявності препаратів в аптеках, то африканські країни також відчувають проблеми через особливі кліматичні і територіальні умови. Наявність пустелі, малонаселенність деяких регіонів зумовлює недостатню кількість аптек, їх віддаленість від основних центрів лікарського забезпечення і, відповідно, - недостатню фрізичну доступність препаратів. Дослідження, проведені в 2013-2014 роках, показують,

ISSN 2312-0967. Pharmaceutical review. 2015. № 4 
Фармацевтичний менеджмент, маркетинг та логістика Pharmaceutical management, marketing and logistics

що в Судані фрізична доступність на деякі ЛЗ була низькою і в державному, і в приватному секторах як для оригінальних Л3 (<10\%), так і для генериків (40-50 \%), між ними відзначені значні цінові відмінності. Значно більше розбіжності у Судані за ціною між оригінальними і генеричними Л3 (може досягати більше 100 \%, хоча у країнах Європи цей показник знаходиться в межах 45-60 \%).

Корисність проведення аналізу доступності генеричних Л3, особливо для країн з системами охорони здоров'я, що формуються, полягає в тому, що за його допомогою можливе швидке та не витратне визначення рівня доступності ліків для населення, своєчасне реагування у випадку погіршення показників, регулювання державної політики країн у сфрері ціноутворення на Л3, а також координування використання оригінальних та генеричних препаратів, що дозволить скоротити бюджетні витрати на лікарське забезпечення без втрати якості лікування.

Висновки. 1. Запропоновано алгоритм дій для визначення економічної доступності ЛЗ, який дозволяє

\section{Список літератури}

1. Вивченняспоживання лікарськихзасобів за анатомотерапевтично-хімічною класифрікацією та встановленими добовими дозами (ATC/DDD - методологія): метод. рек. / А. М. Морозов, Л. В. Яковлєва, А. В. Степаненко та ін. - Харків : Стиль-Издат. - 2013. - 34 с.

2. Громовик Б. П. Фармацевтичний маркетинг: теоретичні та прикладні засади / Б. П. Громовик, Г. Д. Гасюк, О. Р. Левицька. - Вінниця : Нова Книга, 2004 $-464 \mathrm{c}$

3. Довгун С. С. Оценка стоимости и экономической доступности ноотропных препаратов, назначаемых больным с инсультом / C. С. Довгун // Современные проблемы науки и образования. - 2012. - № 2. - С. 3339.

4. Вивчення доступності основних лікарських засобів в Україні: результати спільного проекту ВО3, НАІ та MO3 України / Т. М. Думенко, В. Д. Парій, Л. В. Яковлева, А. Б. Зіменковський // Фармакоекономіка в Україні: стан та перспективи розвитку: матеріали VI науковопрактичної конференції (м. Харків, 22 листопада 2013 р.) / редкол. : В. П. Черних та ін. - Харків : Вид-во НФаУ, 2013. - С. 180-181.

5. Перегінець І. Б. Доступність основних лікарських засобів в Україні: результати фармакоепідеміологічного дослідження (спільний проект ВOO3, HAI та MO3 України) / І. Б. Перегінець, Т. М. Думенко. - Київ, 2324 жовтня 2013 року. [Электронний ресурс]. - Режим доступу: http://old.dec.gov.ua/site/file_uploads /ua/sem/7_ rac_farm/4.pdf

6. Measuring medicine prices, availability, affordability and price components - 2ND edition. World Health Organization підвищити оперативність моніторингу ринку, зменшити трудомісткість отримання даних та їх аналітичної обробки

2. Проведено аналіз економічної доступності генеричних препаратів за найнижчою ціною, що входять до міжнародного переліку, рекомендованого ВООЗ для проведення постійного моніторингу, в країнах Східного Середземномор'я, країнах Афрриканського та Європейського регіонів. Результати аналізу свідчать про недостатню економічну доступність основних ЛЗ в африканських країнах. Проведений порівняльний аналіз економічної доступності Лз країн Асррики з показниками Німеччини свідчать про складну ситуацію 3 лікарським забезпеченням в Судані, де показники доступності на ЛЗ відрізняються від показників сусідніх країн в 7-10 разів, і в 20-30 разів - порівняно з Європою.

3. Узагальнено досвід міжнародних організацій щодо формування системи моніторингу стану лікарського забезпечення африканських країн.

and Health Action International. - [Электронний ресурс]. - Режим доступа: http://www.who.int/ medicines/areas/ access/OMS Medicine prices.pdf

7. Database of medicine prices, availability, affordability and price components. [Электронний ресурс]. - Режим доступа: http://www.haiweb.org/MedPriceDatabase/

8. Medicine prices, availability, affordability \& price components. Ukraine. Palliative care. [Электронний peсурс]. - Режим доступа: http://www.haiweb.org/ medicineprices surveys/200709UAP/sdocs/EMP_ Ukraine\%20palliative\%20Final.pdf

9. Medicine prices, availability, affordability and price components. Ukraine. Survey date: March 2012. [Электронний ресурс]. - Режим доступу: http://www. haiweb.org/medicineprices/surveys/201203UAE/sdocs/ Summary_report_ukraine_mar2012.pdf

10. Medicine Prices, Availability, Affordability and Price Components in Sudan. Survey date: March 2012, Report date: April 2014. [Электронний ресурс]. - Режим доступу: http://www.haiweb.org/medicineprices/surveys/201203SD / sdocs/Sudan_report_2012_FINAL.pdf

11. Medicine Prices, Availability and Affordability in Sudan. Report of a survey conducted in February - March 2013. [Электронний ресурс]. - Режим доступу: [Електронний ресурс]. - Режим доступу: http://www.haiweb.org/ medicineprices /surveys/201302SD/sdocs/Sudan_survey_ report_2013.pdf

12. Salah Ibrahim Kheder. Evaluating medicines prices, availability, affordability and price components in Sudan I Salah Ibrahim Kheder, Hassan Mohamed Ali // Sudan Medical Monitor. - 2014. - Vol. 9, Issue 1. - P. 19-30.

ISSN 2312-0967. Фармацевтичний часопис. 2015. № 4 
Фармацевтичний менеджмент, маркетинг та логістика

Pharmaceutical management, marketing and logistics

\title{
ВОПРОСЫ ЭКОНОМИЧЕСКОЙ ДОСТУПНОСТИ ЛЕКАРСТВЕННЫХ СРЕДСТВ НА АФРИКАНСКОМ
} КОНТИНЕНТЕ

\author{
Е. Н. Евтушенко, Осама Абузаид Мохамед Нур Ахмед \\ Национальный фрармачевтический университет, Харьков
}

Резюме: статья посвящена исследованию экономической доступности лекарственных средств на Африканском континенте с помощью методологии Всемирной организации здравоохранения (World Health Organization WHO) и Международной программы действий в здравоохранении (Health Action International - HAI), a также показателей экономической доступности лекарственных средств в разных странах. Полученные результаты свидетельствуют о недостаточной фризической доступности основных лекарственных препаратов в асрриканских странах. Проведенный сравнительный анализ с показателями Германии свидетельствует о сложной ситуации с лекарственным обеспечением в Судане, где показатели доступности хуже показателей африканских стран в 7-10 раз, и в 20-30 раз - в сравнении с европейской страной.

Ключевые слова: лекарственные средства, экономическая доступность, африканские страны, Судан, Германия.

\section{ISSUES OF ECONOMIC AVAILABILITY OF MEDICINES ON THE AFRICAN CONTINENT}

\section{O. M. levtushenko, Osama Abuzaid Mohamed Nur Ahmed}

National Pharmaceutical University, Kharkiv

Summary: the article is devoted to economic availability of medicines on the African continent with the help of the methodology of the World Health Organization (World Health Organization - WHO) and the International Programme of Action in Health Care (Health Action International - HAI), as well as indicators of affordability of drugs in different countries. The results indicate a lack of physical availability of essential drugs in African countries. Comparative analysis with indicators of Germany demonstrates the difficult situation with the drug provision in the Sudan, where indicators are worse than the availability of African countries 7-10 times, and 20-30 times - in comparison with European country.

Key words: medicines, affordability, African countries, Sudan, Germany. 